\title{
Uma leitura psicanalítica sobre as metodologias
}

\author{
[CAMARGO, A. C. C. S. Educar: uma questão \\ metodológica? Proposições psicanalíticas sobre o ensinar e o \\ aprender. Petrópolis, RJ: Vozes, 2006, 141p. (Coleção \\ Psicanálise e Educação, dirigida por Leandro de \\ Lajonquière)]
}

Odana Palhares

O livro aqui apresentado é o testemunho de alguém que ousou fazer primeiro para depois buscar o como e o porquê do seu trabalho. Resultado de um Trabalho Complementar de Curso realizado ao final do curso de Pedagogia, da Faculdade de Educação da USP, no qual a autora, professora particular há vinte e cinco anos, reflete sobre a sua prática e sobre uma das principais questóes que a levaram à Academia. Entre as disciplinas cursadas nessa faculdade, Camargo vai encontrar ressonâncias do seu fazer nas aulas de psicanálise.

São abundantes as publicações que pretendem ajudar o professor na difícil tarefa de ensinar. As metodologias sugerem que, cada vez mais, trata-se de buscar o planejamento correto para alcançar o resultado esperado. Sendo assim, não são pequenas as frustrações enfrentadas pelos professores que pensam fazer tudo o que lhes é indicado e, ainda assim, raramente sentem ter atingido plenamente seus objetivos.

Num discurso crítico sobre as proposições didáticas, por meio de metodologias as mais diversas, a autora apresenta uma revisão dos conceitos e das principais teorias que versam sobre o assunto. Esse panorama geral é acompanhado de comentários, ora elucidativos, ora críticos, às vezes suaves e outras bastante contundentes.

$\mathrm{Na}$ leitura dos cinco capítulos, faz-se o seguinte percurso: os sentidos do educar; a pedagogia científica; a ética do sujeito; a questão da metodologia e as considerações finais. Embora a metodologia seja a questão central, este não é um livro de metodologia. A reconstituição das múltiplas idéias ou dos saberes

* Doutoranda no Grupo de Pesquisa Pensamento e Linguagem (GPPL) da FE-Unicamp. odana@uol.com.br 
sobre o ensinar tem o intuito da crítica que lança perguntas para abrir caminhos, propósito ao qual a autora se lança de forma coerente do começo ao fim de seu trabalho.

Para cumprir seu objetivo, Camargo parte, inicialmente de forma metódica, dos sentidos da palavra educar, apresentando as nuances e as ambigüidades a que o termo pode dar margem. Faz uma crítica à didática de tradição positivista, a qual predomina ainda nos dias de hoje, bem como ao ideário da educação. Responde à questão-título, apresentando a concepção psicanalítica sobre os atos de ensinar e aprender. Mesmo não tendo a pretensão de ensinar nada aos professores, acaba "ensinando" um modo de fazer educação sem receitas.

Não se engane o leitor com a sistematicidade com a qual o assunto é tratado. $\mathrm{O}$ cuidado que a autora emprega ao resgatar tanto os sentidos do educar quanto a cientificidade da pedagogia é proporcional ao incômodo que causa, para aqueles que gostariam de se manter confortáveis nas metodologias existentes.

Fiel ao pensamento psicanalítico, Camargo afirma que, para além das metodologias de ensino, é a forma como o educador se enlaça à cultura e às disciplinas que pretende ministrar, que marca a diferença com a relação estabelecida no próprio ato de ensinar.

Ao fazer essa afirmação propõe, conforme a psicanálise, a ética do sujeito. No contraponto para a questão-título tece uma crítica à educação ideal - sonho da Pedagogia Ortodoxa - e apresenta algumas idéias que a psicanálise tem sobre a educação, mais especificamente sobre o ensinar e o aprender, colocando a ética da psicanálise como contribuição à educação. Essa dimensão ética consiste no respeito à subjetividade, e o educador que pode levá-la em conta não terá grandes dificuldades para abrir mão do controle obsessivo pela normatização dos comportamentos.

O estudo da psicanálise não é sem conseqüências e isso fica claro nessa obra em que a autora não se dedica à crítica pela crítica, mas faz uma análise do próprio percurso - por sinal muito singular - e implica-se nas questóes colocadas. Nunca foi tão verdadeiro o pensamento veiculado popularmente "É caminhando que se faz caminho", pois, ao começar a dar aulas, tendo como referência "apenas" a sua experiência de aluna, sem nenhuma contaminação dos diversos saberes sobre o ensinar e o aprender, e sem dúvida carregando consigo a educação familiar que recebeu, Camargo não renuncia ao ato educativo. Ao receber os alunos que estão encontrando alguma ou algumas dificuldades no processo de aprendizagem, a autora trilha com eles os caminhos tortuosos da educação.

Ao ler este livro, lembrei-me do filme O Feitiço de Áquila (Ladyhawke, 1985), mais especificamente do personagem Phillipe Gaston, "o rato". Mesmo não sendo o personagem principal, faz toda a diferença no filme. Há uma cena em que perguntam a ele, um menino de aproximadamente catorze anos, como 
conseguiu escapar de Áquila, a prisão mais segura e temida naquele tempo, ao que ele responde: Não sei, caí num buraco e segui meus instintos. Nesse momento, a cena mostra a sua lembrança do fato: ele caindo num buraco estreito, pelo qual tem que passar uma parte do corpo de cada vez, terminando com um braço, outro braço e, por último, a cabeça. É quando ele diz que aquilo foi como nascer de novo!

O texto é instigante e a partir da leitura podem-se seguir diversos caminhos: remeter-se à história da pedagogia; buscar o conhecimento das metodologias; ou lançar-se ao ato de ensinar, sabendo que devemos enfrentar os riscos que corremos ao viver, pois, assim como não há um manual de vida que sirva para todos, não há um manual de educação, por mais que as metodologias, na melhor das intençôes, procurem indicar como o educador deve proceder.

É uma obra original e valiosa, porque aborda uma das questões que mais preocupa os educadores. Caberá a cada um, ao percorrer estas páginas, decidir o caminho a seguir. De qualquer forma, terá valido a pena a leitura dessa interrogação transformada em livro.

O testemunho da autora trouxe-me a imagem acima, de alguém que seguiu seus instintos e nasceu. Fica o convite ao leitor para que se inspire nessa trajetória corajosa, confie mais em si mesmo e renasça! 